\title{
CREDIT RISK AND BANK STABILITY OF VIETNAM COMMERCIAL BANK: A BK APPROACH
}

\section{SANG TANG MY*}

Ho Chi Minh City University of Economics and Finance (UEF). 141-145 Dien Bien Phu Street, Ward

\author{
15, Binh Thanh District, Ho Chi Minh City, VietNam
}

*Corresponding author: sangtm@uef.edu.vn

\begin{abstract}
Through the secondary data collected from 2005 to 2019, we used the BK approach in which, Pooled OLS, FEM, REM, and GMM methods and Sobel's test are used to check the relationship between bank credit risk and bank stability of Vietnam commercial bank system. The results show that bank credit risk, profitability, and bank stability have a direct relationship and have a partial indirect relationship. The size and profitability of the previous period have a positively correlated with bank profitability, nonperforming loan, loan loss provision, non-interest income, efficiency, and bank credit growth have a negative impact on bank profitability, bank profitability has no impact on bank credit risk. Profitability and bank stability of the previous period have an impact on current bank stability. Nonperforming loans, non-interest income hurt bank stability, loan loss provision and bank stability of the previous period have a positively correlated with current bank stability.
\end{abstract}

\section{INTRODUCTION}

Financial stability is the foundation for sustained economic growth in every country. So, this attaches the attention of governments, international organizations such as the World Bank, International Monetary Organization, and all regions of the world. Countries have identified financial stability as a condition for macroeconomic stability due to the close link between these two goals. Money and banking is an extremely sensitive field, affected by many different factors,

Received September 17th, 2020; accepted October 8th 2020 ; published November $3^{\text {rd }}, 2020$.

2010 Mathematics Subject Classification. 91G40.

Key words and phrases. bank stability; credit bank; bank performance.

(C2020 Authors retain the copyrights of their papers, and all open access articles are distributed under the terms of the Creative Commons Attribution License. 
therefore, bank stability, monetary stability are considered as an important factor in the goal of financial stability.

In the financial system, a commercial bank is one of the largest financial institutions, supply the capital for corporations, households, individuals, and other organizations. Because commercial bank role as the main intermediary financial institution of the economy, the operation of the commercial banking system has a great impact on other entities, especially corporations, and then affects economic growth. Since then, the bank's activities have received much attention from the objects of the economy, especially about bank efficiency.

The bank's performance depends on various factors such as profitability, innovation, service quality [22] of which the most important factor considered is bank credit risk. There's a positive relationship between profitability and liquidity of 12 banks in Europe, North America, and Australia [12]. The relationship between profitability and capital ratio of American banks is positive in the 1980s [10]. The relationship between bank credit risk and the profitability of commercial banks is positive in Switzerland [28]. One of the most important factors that have a direct impact on the business performance of banks is non-performing loans ([7], [38], [27]).

Theoretically, credit risk is the most important risk, stemming from the operational nature of commercial banks, credit risk is the result of the adverse selection and moral hazard. This risk hurts the performance of commercial banks. Frederic S. The commercial banks want to earn high profits, they must recover all loans to customers, only need a small percentage of non-performing loan can lead to commercial bank failures [30]. Because of this importance, the operation of the banking system is subject to a lot of different rules, one of the principles applied by the global commercial banking system in the governance process is Basel Accord, developed by the Basel Committee. Up to now, Basel has undergone 3 revisions, helping banks to maintain a stable position in the complicated fluctuations of the financial market. One of the contents identified by the Basel Committee is credit risk management because effective credit risk management will help banks increase profitability and then help the bank system more stability, contribute to stabilizing the financial system, and allocate capital in the economy more effectively.

After the recent financial crisis, the number of failed banks increased, leading to a lot of complicated and difficult problems. These issues are clearly expressed in the financial statements of banks, from which the world financial market has focused more on the business performance 
of the commercial banking system and especially credit risk because there is evidence that credit banks have an impact on financial stability [37].

As the main source of capital in the economy, the profitability of Vietnam's commercial bank system has a great impact on the operation of corporations and the stability of the financial system. In the period from 2015 to 2018, profitability improved markedly, increasing from $6.42 \%$ in 2015 to $9.06 \%$ in 2018 . The improvement in the profitability of Vietnam commercial banks in 2018 is considered to be the average level of Southeast Asia since the global crisis in 2008. According to the National Financial Supervisory Commission, the operation of the bank system is still facing many challenges such as non-performing loans and rising costs. The total value of non-performing loans of 22 banks to March 2019 was about VND 84 trillion, an increase more than VND 4.6 trillion, about 5.9\% compared to the end of 2018 while the growth of outstanding loans was only at 3.46\%, of which 15 banks have increased NPLs. Among the non-performing loan groups, the owe losses-loss loans account for a high proportion, affect to credit growth, the credit growth of this period was lower than in 2017 and 2018 [6].

Bank credit growth fall and high non-performing loan greatly affect the income and efficiency of Vietnam commercial banking system. For example, Bank for Investment and Development of Vietnam (BIDV), the largest bank in Vietnam in 2019, due to high non-performing loan, they have to make provision and profit after provisioning has fallen by nearly $80 \%$ compared to the original. In the banking sector development strategy, the State Bank has identified the period from 2005 to 2020 as a stage of building a safe, healthy, competitive, and sustainable banking system. Therefore, bank stability is also identified as a very important target of the bank system. To strengthen bank stability, improve efficiency and reduce bank credit risk in the coming period, Vietnam's banking system needs to have effective and appropriate management measures, as well as to identify the overall factors including internal and external elements, to make appropriate forecasts and strategies for hedging the increasingly complex developments of the macro environment.

\section{LITERATURE REVIEW}

Credit risk is defined as a potential change in net income and market value of capital resulting from a client's failure to pay or to make a late repayment [38]. Credit risk is the biggest risk in an accounting book of a bank and if not properly managed, it can lead to a bank financial weakening 
[25]. This is a potential risk in which the customer can not meet its obligations under the agreed terms [9]. In 2001, the Basle Committee identified additional credit risk as to the main risk in the operation of commercial banks, the risk associated with the bank's key activities, related to capital mobilization and lending. So, credit risk is the risk arising in the process of credit extension of banks, in which customers cannot repay debts or repay debts on time to banks.

The impact of credit on bank performance received great interest from researchers. Internal factors such as loan loss provision, the ratio of equity to total assets, and operating costs have an impact on bank profits with high significance [7].

Bank performance is defined as the ability to minimize costs or maximize the profit of banks [10]. The performance of commercial banks is reflected in the relationship between output and input of commercial banks. Specifically, commercial banks generate the largest output with the smallest input [10]. Bank performance is interested in managers and investors because high performance will help banks preserve capital, increase market share, and attract investment. Bank performance is the net income after tax of commercial banks [30], which is the net profit of the bank [33], involving the return on the initial investment ([9], which is an increase in profit compared to operating costs [39]. This ratio is used to measure the profit made by the bank based on revenue, capital, assets, and earnings per share. Bank performance is one of the indicators showing growth and success in banking operations [29], which is the final goal of investment, demonstrating the efficiency of resource management [27], expressed in two ways including accounting profit and economic profit [5]. Corporations often have more benefits when performance increases. To measure the bank performance of a bank, various methods can be used but financial indicators are the most common method [33]. Theoretically, ROE is favored more than other indicators ([21], [15]). In an increasingly competitive environment, bank performance is one of the key factors that help the bank operate smoothly, continuously, and have a direct impact on its development process [38]. Studying bank performance is very important because this is not only the most important factor in the existence of a bank but also provides information about the health of the bank system.

Bank stability is the status of effective implementation of important economic functions such as resource allocation, dispersion, and risk handling, which is the ability to fully absorb the shock the system faces [16], assess changes in financial risks, and effective allocation of resources [23], shows the flexibility of all financial-related activities and sectors to minimize losses and bank 
crises [5]. Bank instability comes from inefficient banks leading to liquidity risk which leads to shocks [37] and economic efficiency is likely to be reduced due to financial fluctuations [15].

Z-score is considered as an indicator of bank stability. A higher Z-score indicates a more stable bank ([16], [17], [10], [20]). Because of this importance, some studies have been carried out in various aspects to test and identify signs of instability to take countermeasures. The research study on the agricultural banking system in Ghana shows that the risk of capital mobilization and the stability of the bank also tend to fluctuate in the same direction [2]. Determinants of bank stability is the differences between banks and the type of banks [18].

To study the relationship between bank credit risk and bank profitability, the research used the theories including Efficiency Theory [3], The Agency Cost Theory [26]. Efficiency theory proposed that good governance and effective banks are more profitable, efficiency management not only increases profits but also helps banks increase market share and improve market concentration [7]. For the banking industry, the efficient theory said that large banks have better governance and management experience, so they can reduce operating costs, and profit will be higher than small banks [36]. Besides, the efficiency theory also suggests that efficiency operating effects to bank profitability by reducing operating costs [10].

The agency cost theory assumes that the financial structure of a firm is used by managers as a means of dealing with cash flow problems. In the organization structure of joint-stock enterprises, managers and owners are two different objects in which managers represent for the owner to manage the company and they may take actions that are inconsistent with the owner's goal resulting in agency costs. This cost is divided into three sub-groups including management supervision cost, bond cost, and the remaining costs [26].

\section{RESEARCH OBJECTIVES:}

The research was conducted to study the relationship between credit risk and bank stability of the Vietnam commercial bank system, thereby propose solutions to increase bank stability of the bank system. The specific objective is to check the relationship between credit risk and bank performance, the relationship between credit risk and bank stability, the relationship between bank performance and bank stability of Vietnam commercial bank. Suggest solutions to decrease bank credit risk and improve bank stability for Vietnam commercial banks.

\section{Data and Methodology:}

\subsection{Research data and estimation methodology}


The research uses a panel data of 286 observations collected from the financial statements from 2005 to 2019, in which some data collected from Bankscope and some microeconomic data from the ADB Indicators.

Because credit risk and bank stability is mediation relationship, so BK approach is used to solve the data, this method used to demonstrate that using the regression technique suffers from a serious drawback, this produces larger standard errors for the path coefficients, so the results are inaccurate and not comprehensive [24]. According to the BK approach, to measure all relationships between variables in the model. The first step will be to measure the direct relationship between variables in the model. If the measurement result has a relationship that is not statistically significant, there is no mediation and the researcher should stop. Conversely, if all models are statistically significant, continue to the second step. In the second step, the result obtained from Sobel's coefficient will be used to conclude the intermediate relationship of the model. To check the direct relationship, the research uses time-series data, the model estimation method chosen is Pooled OLS, FEM, REM, GLS, and GMM method [24].

\subsection{Model and hypotheses:}

Empirical studies on credit risk and bank performance with three main research trends including checking the relationship between profitability and bank stability, the relationship between credit risk and bank performance, and the relationship between credit risk and bank stability, this is the basis for selecting relevant research models. Most models from empirical research use multivariate regression models with panel data for commercial banks of each country or many countries. This study approach towards research on the choice of the model comes from two reasons. Firstly, choose a multivariate regression model, using panel data of Vietnam commercial banks from 2005 to 2019. Secondly, to ensure the estimation of the regression model is accurate, choosing the appropriate variables, the authors have conducted a multi-collinear test, variance change, and autocorrelation. Besides, Pooled OLS, FEM, REM, GLS, and GMM methods are used to test the hypotheses proposed, this approach is consistent with research trends.

The selection of basic variables and making research hypotheses are mainly based on empirical evidence, mainly from the research of Athanasoglou [7] and Diaconu [18]. The research proposes three models for three phases, the first phase will determine the factors that affect to bank's credit risk, the second phase will study the impact of profitability on bank performance, the third phase will study the impact of credit risk on bank stability. Model in the first phase as follows: 
$R O E=\alpha_{0}+\sum_{j=1}^{J} \beta_{j} X_{i t}^{J}+\sum_{l=1}^{L} \beta_{l} X_{i t}^{l}+\varepsilon_{i t}$ (1)

Where ROE is the bank performance of bank i. $\alpha_{0}$ is constant. $\mathrm{X}$ are independent variables, group $\mathrm{j}$ includes internal factors of the bank (liquidity, non-performing loan, loan loss provision, bank size, leverage, non-interest income, efficiency, bank credit growth). $\beta_{l}$ is the impact of the independent variable on bank performance. $\beta_{j}$ is the effect of the lag variable on bank performance. $\varepsilon_{i t}$ is the disturbance. Based on the research of Athanasoglou [7] and Diaconu [18], variables of the model are shown in table 1.

Table 1. Variables of the model (1)

\begin{tabular}{|l|l|l|l|}
\hline Variables & Description & Expected effect & Authors \\
\hline $\begin{array}{l}\text { Non-performing } \\
\text { loan (NPL) }\end{array}$ & Non-performing loan/ Total Loans & - & Berger (1997) \\
\hline $\begin{array}{l}\text { Loan loss } \\
\text { provision (LLR) }\end{array}$ & Loan loss provision/ Total Loans & - & Chaibi (2003) \\
\hline Leverage (LEV) & Liabilities / Total Asset & + & Abreu (2000) \\
\hline $\begin{array}{l}\text { Non-interest } \\
\text { income (NII) }\end{array}$ & Non-interest income/ Total income & + & $\begin{array}{l}\text { Alexiou (2009) } \\
\text { Dietrich (2011) }\end{array}$ \\
\hline $\begin{array}{l}\text { Bank Size (SIZE) } \\
\text { Natural log total assets }\end{array}$ & $\begin{array}{l}\text { Pasiouras (2007) } \\
\text { Guillen (2014) }\end{array}$ \\
\hline $\begin{array}{l}\text { Efficiency (EFF) } \\
\text { Operation cost /Operation income }\end{array}$ & - & $\begin{array}{l}\text { Memmel (2010) } \\
\text { Hoffmann (2011) } \\
\text { Pasiouras (2007) }\end{array}$ \\
\hline $\begin{array}{l}\text { Liquidity (ETA) } \\
\text { growth (CRG) }\end{array}$ & $\begin{array}{l}\text { Equity/ Total asset } \\
\text { year t-1)/ Total loans at year t-1 }\end{array}$ & $\begin{array}{l}\text { Radic (2012) } \\
\text { Berger (1997) }\end{array}$ \\
\hline
\end{tabular}

Source: summary of previous studies

In the second phase, to examine the relationship between bank stability and bank performance, the research use the model based on research by Tan [39]

$y_{i t}=\alpha_{0}+\alpha_{1} y_{i, t-1}+\alpha_{2} y_{i, t-2}+\beta_{1} x_{i, t-1}+\beta_{2} x_{i, t-2}+\theta_{t}+\delta_{i}+\mu_{i t}(2)$ 
Where $y$ is bank performance (ROE), $x$ is bank stability (Z-score), $\mathrm{i}$ and $\mathrm{t}$ represent for bank $\mathrm{i}$ in year $\mathrm{t}, \alpha_{0}$ is the intercept, $\alpha_{1}, \alpha_{2}, \beta_{1}, \beta_{2}$ are the coefficients to be estimated, $\theta_{t}$ is the time effect, $\delta_{i}$ stands for individual bank effect, and $\mu_{i t}$ is the error term, $\mu_{i t}$ is the error term.

Z-score $=[\mathrm{E}(\mathrm{ROAA})+\mathrm{Ebq} / \mathrm{Abq}] / \sigma(\mathrm{ROAA})$

Where ROAA is the return on average of total assets. Ebq/ $\mathrm{Abq}$ is the ratio of average equity to an average of total assets. oi(ROAA) is the standard deviation of ROAA

Model in the final phase used to study the impact of profitability on bank stability

$Z-$ score $=\alpha_{0}+\sum_{j=1}^{J} \beta_{j} X_{i t}^{J}+\sum_{l=1}^{L} \beta_{l} X_{i t}^{l}+\varepsilon_{i t}(3)$

Where ROE is bank performance i. $\alpha_{0}$ is constant. $\mathrm{X}$ are independent variables, group j includes internal factors of the bank (liquidity, credit risk, capital ratio, bank size, operating expenses) and group 1 includes macro factors (inflation, economic growth). $\beta_{l}$ is the impact of the independent variable on profitability. $\beta_{j}$ is the effect of the lag variable on the profitability of the bank. $\varepsilon_{i t}$ is the disturbance. Based on the research of Athanasoglou [7] and Diaconu [18], independent variables of the model are shown in table 2.

Table 2. Variables of the model (3)

\begin{tabular}{|c|c|c|c|}
\hline Variables & Description & Expected effect & Authors \\
\hline Liquidity (ETA) & Total Loans/ Total Assets & + & Ongore (2014) \\
\hline $\begin{array}{l}\text { Non-performing } \\
\text { loans (LLP) }\end{array}$ & $\begin{array}{l}\text { Non-performing loans / Total } \\
\text { Loans) }\end{array}$ & - & Hasan (2003) \\
\hline $\begin{array}{l}\text { Loan loss provision } \\
\text { (LLP) }\end{array}$ & Loan loss provision/ Total Loans & - & $\begin{array}{l}\text { Athanasoglou (2006) } \\
\text { Diamond (2011) } \\
\text { Dang (2011) }\end{array}$ \\
\hline Efficiency (EFF) & Operation cost / operation Income & + & $\begin{array}{l}\text { Obamuyi (2013) } \\
\text { Memmel (2010) }\end{array}$ \\
\hline Bank size (SIZE) & Natural log total assets & + & $\begin{array}{l}\text { Bowa (2015) } \\
\text { Hoffmann (2011) }\end{array}$ \\
\hline $\begin{array}{l}\text { Non-interest income } \\
\text { (NII) }\end{array}$ & Non-interest income/ Total income & + & Alexiou (2009) \\
\hline $\begin{array}{l}\text { Bank credit growth } \\
\text { (CRG) }\end{array}$ & $\begin{array}{l}\text { (Total loans at year } \mathrm{t}-\text { Total loans at } \\
\text { year } \mathrm{t}-1 \text { )/ Total loans at year } \mathrm{t}-1\end{array}$ & - & Carlson (2019) \\
\hline
\end{tabular}




\section{EMPIRICAL ANALYSIS}

The descriptive statistics of the research are shown in table 3. This indicates that the dispersion between observations in the sample is expressed as mean, maximum, minimum, and standard deviation. The values of variables are unevenly distributed, through mean and standard deviation. The data is unbalanced.

Table 3. Descriptive statistics

\begin{tabular}{|c|c|c|c|c|c|}
\hline Variables & Obs & Mean & $\begin{array}{l}\text { Standard } \\
\text { deviation }\end{array}$ & Min & Max \\
\hline $\mathrm{npl}$ & 349 & .0198539 & .0135546 & .0002 & .1032 \\
\hline roe & 384 & .0986214 & .0829285 & -.82 & .3714 \\
\hline size & 384 & 17.95054 & 1.550093 & 11.8835 & 20.9956 \\
\hline nii & 383 & .2199755 & .6205942 & -2.1087 & 11.6503 \\
\hline lev & 384 & .8897294 & .134121 & -.422 & 1.7112 \\
\hline$\overline{\text { eff }}$ & 375 & .5024067 & .1916247 & .1741 & 2.2091 \\
\hline $\mathrm{crg}$ & 380 & .4343045 & 1.020566 & -1 & 11.3268 \\
\hline eta & 380 & .1023092 & .0616704 & .0041 & .4624 \\
\hline llr & 386 & .3474319 & 4.39156 & -.0071 & 86.3019 \\
\hline Z_score & 371 & 2.262678 & 1.804082 & .0528 & 12.5477 \\
\hline
\end{tabular}

Source: calculating from Stata 12.

The correlation coefficient matrix in three models shows the results that the correlation coefficients are relatively small, without serious multi-collinear phenomena due to low correlation coefficients value, the comparison standard is 0.8. Checking the multicollinearity phenomenon with the VIF coefficient, the result shows that the VIF of all independent variables is less than 10 .

Firstly, the study uses the regular panel data regression model with the Pool OLS method to estimate the regression equations and test some hypotheses of the OLS model. After that, the research estimated all three models: Pooled, FEM, and REM, but due to the variance change, White test results with Prob> chi $2=0.0000$, less than $1 \%$, so the research will eventually regress according to GMM method. The results of the regression of model 1 shown in table 4 Table 4. Summary of regression results of model 1 


\begin{tabular}{|c|c|c|c|c|}
\hline & Pooled OLS & FEM & REM & GMM \\
\hline & ROE & ROE & ROE & ROE \\
\hline \multirow[t]{2}{*}{ SIZE } & $0.0123^{* * *}$ & $0.0102^{* * *}$ & $0.0113^{* * *}$ & $0.0153^{* * *}$ \\
\hline & [4.39] & {$[2.70]$} & [3.42] & {$[4.81]$} \\
\hline \multirow[t]{2}{*}{ NII } & $-0.0750 * * *$ & $-0.0770 * * *$ & $-0.0765^{\star * *}$ & $-0.0827^{* * *}$ \\
\hline & [-17.88] & [-19.55] & [-19.83] & [-28.98] \\
\hline \multirow[t]{2}{*}{ LEV } & $0.0840^{* * *}$ & $0.0832^{* * *}$ & $0.0830^{* * *}$ & 0.0552 \\
\hline & {$[2.74]$} & {$[2.81]$} & [2.88] & [1.45] \\
\hline \multirow[t]{2}{*}{ LLR } & $-1.456^{* * *}$ & $-1.909^{* * *}$ & $-1.818^{* * *}$ & $-1.980^{\star * *}$ \\
\hline & {$[-4.17]$} & {$[-5.29]$} & {$[-5.24]$} & {$[-7.88]$} \\
\hline \multirow[t]{2}{*}{ EFF } & $-0.318^{* * *}$ & $-0.306^{* * *}$ & $-0.312^{* * *}$ & $-0.283^{* * *}$ \\
\hline & {$[-15.63]$} & {$[-14.02]$} & [-15.17] & {$[-19.06]$} \\
\hline \multirow[t]{2}{*}{ CRG } & -0.00177 & -0.00125 & -0.00127 & $-0.00307^{* * *}$ \\
\hline & {$[-1.09]$} & {$[-0.84]$} & {$[-0.87]$} & {$[-3.26]$} \\
\hline \multirow[t]{2}{*}{ NPL } & -0.425 & -0.326 & -0.322 & $-0.756^{*}$ \\
\hline & {$[-1.51]$} & {$[-1.17]$} & {$[-1.19]$} & {$[-1.67]$} \\
\hline \multirow[t]{2}{*}{ ETA } & -0.0879 & $-0.122^{*}$ & -0.111 & -0.0700 \\
\hline & {$[-1.18]$} & {$[-1.71]$} & {$[-1.59]$} & {$[-0.99]$} \\
\hline \multirow[t]{2}{*}{ L.ROE } & & & & $0.197^{* * *}$ \\
\hline & & & & [2.59] \\
\hline \multirow[t]{2}{*}{ _CONS } & 0.00518 & 0.0440 & 0.0232 & -0.0468 \\
\hline & {$[0.08]$} & {$[0.58]$} & {$[0.34]$} & {$[-0.57]$} \\
\hline $\mathbf{N}$ & 317 & 317 & 317 & 274 \\
\hline R-SQ & 0.672 & 0.696 & & \\
\hline
\end{tabular}

t statistics in brackets * $\mathrm{p}<0.1,{ }^{* *} \mathrm{p}<0.05,{ }^{* * *} \mathrm{p}<0.01$

Source: calculating from Stata 12

In model 2, four methods including Pooled OLS, FEM, REM, and GLS used to process data, but due to the variance change, the White test results Prob $>$ chi $2=0.0000$, less than $1 \%$ so the research will regress according to the GLS method. The result is shown in table 5. 
Table 5. Summary of regression results of model 2

\begin{tabular}{l|llll}
\hline & Pooled OLS & FEM & REM & GLS \\
& Z_score & Z_score & Z_score & Z_score \\
\hline Z_score-1 & $0.336^{* * *}$ & $0.212^{* * *}$ & $0.336^{* * *}$ & $0.185^{* * *}$ \\
Z_score-2 & {$[5.67]$} & {$[3.48]$} & {$[5.67]$} & {$[3.19]$} \\
& -0.0188 & $-0.107^{*}$ & -0.0188 & 0.0122 \\
ROE-1 & {$[-0.32]$} & {$[-1.78]$} & {$[-0.32]$} & {$[0.21]$} \\
& $-2.535^{*}$ & $-3.034^{* *}$ & $-2.535^{*}$ & $-2.674^{* *}$ \\
ROE-2 & {$[-1.93]$} & {$[-2.20]$} & {$[-1.93]$} & {$[-2.06]$} \\
& -0.752 & -1.638 & -0.752 & -1.115 \\
_cons & {$[-0.57]$} & {$[-1.19]$} & {$[-0.57]$} & {$[-0.87]$} \\
& $2.071^{* * *}$ & $2.697^{* * *}$ & $2.071^{* * *}$ & $2.409^{* * *}$ \\
$\mathrm{~N}$ & {$[8.46]$} & {$[9.81]$} & {$[8.46]$} & {$[8.92]$} \\
\hline R-sq & 317 & 317 & 317 & 317 \\
\hline
\end{tabular}

t statistics in brackets

${ }^{*} \mathrm{p}<0.1,{ }^{* *} \mathrm{p}<0.05,{ }^{* * *} \mathrm{p}<0.01$

Source: calculating from Stata 12.

To test model 3, the research also uses four methods including Pool OLS, FEM, REM, and GMM to estimate, autocorrelation phenomena, variance change, multicollinearity do not occur and the estimation results in table 6 show that the GMM method is most suitable. 
Table 6. Summary of regression results of model 3

\begin{tabular}{|c|c|c|c|c|}
\hline & Pool OLS & FEM & REM & GMM \\
\hline & Z_score & Z_score & Z_score & Z_score \\
\hline \multirow[t]{2}{*}{$\mathrm{crg}$} & $9.534^{* * *}$ & $15.37^{* * *}$ & $12.75^{* * *}$ & -14.48 \\
\hline & [3.32] & [5.31] & [4.48] & {$[-0.74]$} \\
\hline \multirow[t]{2}{*}{ eff } & $2.572 * * *$ & 0.890 & $2.032^{* * *}$ & -0.505 \\
\hline & [3.85] & [1.21] & [2.98] & {$[-0.69]$} \\
\hline \multirow[t]{2}{*}{ llr } & $30.43^{* *}$ & $28.11^{* *}$ & $30.81^{* *}$ & $26.83^{*}$ \\
\hline & [2.39] & [2.02] & [2.33] & [1.87] \\
\hline \multirow[t]{2}{*}{$\mathrm{npl}$} & $-19.26^{* * *}$ & $-19.85^{\star \star *}$ & $-20.33^{* * *}$ & $-20.97^{* * *}$ \\
\hline & {$[-2.64]$} & {$[-2.81]$} & {$[-2.88]$} & {$[-3.54]$} \\
\hline \multirow[t]{2}{*}{ lev } & 0.00749 & 0.156 & 0.0240 & -33.51 \\
\hline & {$[0.01]$} & [0.13] & [0.02] & {$[-1.56]$} \\
\hline \multirow[t]{2}{*}{ nii } & -0.964 & $-1.231^{*}$ & $-1.208^{*}$ & $-2.613^{* * *}$ \\
\hline & {$[-1.55]$} & {$[-1.85]$} & [-1.89] & {$[-4.36]$} \\
\hline \multirow[t]{2}{*}{ size } & $0.266^{* * *}$ & $0.853^{* * *}$ & $0.502^{* * *}$ & 0.0269 \\
\hline & [2.60] & [6.24] & [4.38] & {$[0.05]$} \\
\hline \multirow[t]{2}{*}{ L.z_score } & & & & $0.121^{* * *}$ \\
\hline & & & & [3.24] \\
\hline \multirow[t]{2}{*}{ _cons } & $-4.479^{*}$ & $-14.95^{\star \star *}$ & $-8.734^{\star * *}$ & 34.07 \\
\hline & {$[-1.84]$} & {$[-5.27]$} & {$[-3.44]$} & [1.60] \\
\hline $\mathrm{N}$ & 326 & 326 & 326 & 270 \\
\hline R-sq & 0.100 & 0.207 & & \\
\hline
\end{tabular}

$\mathrm{t}$ statistics in brackets

${ }^{*} \mathrm{p}<0.1,{ }^{* *} \mathrm{p}<0.05,{ }^{* * *} \mathrm{p}<0.01$

Source: calculating from Stata 12.

In the final step, Sobel's test is used to check the indirect relationship between bank stability, credit risk, and bank stability and the estimation results in table 7 show that there is a partial mediation relationship between the three variables. 
Table 7. The result of Sobel's test

\begin{tabular}{l|l|l|l}
\hline Estimates & Delta & Sobel & Monte Carlo \\
\hline Indirect effect & 9.065 & 9.065 & 9.110 \\
Std. Err. & 2.680 & 2.680 & 2.790 \\
Z-value & 3.383 & 3.383 & 3.265 \\
p-value & 0.001 & 0.001 & 0.001 \\
Conf. Interval & $3.814,14.317$ & $3.814,14.317$ & $3.807,14.606$ \\
\hline
\end{tabular}

Baron and Kenny approach to testing mediation

STEP 1 - roe:npl $(X->M)$ with $B=-1.5 e+03$ and $p=0.000$

STEP 2 - zscore:roe $(\mathrm{M}->\mathrm{Y})$ with $\mathrm{B}=-0.006$ and $\mathrm{p}=0.000$

STEP 3 - zscore:npl (X -> Y) with $B=-17.602$ and $p=0.008$

As STEP 1, STEP 2 and STEP 3 as well as the Sobel's test above

are significant the mediation is partial!

Source: calculating from Stata 12

The research results of model 1 show that the bank size and profitability of the previous year have positively correlated with bank performance. Non-interest income, loan loss provision, bank performance, bank credit growth, and non-performance have negatively correlated with bank performance. These results are consistent with the study of Berger [10], Chaibi [41], Pasiouras [33], Abreu [1].

Research results of the impact of business efficiency on bank stability, the impact of credit risk on bank stability show that non - performing loans, loan loss provision, non-interest income, and bank stability in the previous period have an impact on bank stability.

The research results after 3 steps and Sobel's test show that the mediation relationship is a partial, this means that credit risk affects bank stability through bank performance. Bank stability of the Vietnam commercial bank system depends on both credit risk and bank performance.

- NPL impact on ROE, ROE has no impact on NPL, non-performing loans impact on the bank performance but bank performance has no impact on non-performing loans ;

- ROE impact on Z-score, the bank performance impact on bank stability with one year lag; Zscore-1 impact on Z-score, bank stability of previous period impact on current bank stability.

- NPL impact on Z-score, non-performing loan impact on bank stability;

- NPL, ROE, and Z-score are partial relationships, bank stability is explained by two variables including non-performing loans and bank performance. 


\section{CONCLUSION AND POLICY IMPLICATIONS}

\subsection{Conclusion}

The results obtained from the research models show that, in terms of direct impact, NPL has an impact on ROE and Z-score, ROE has a one-way impact on Z-score. Because the first model does not show the ROE's adverse effect on the NPL, the study of the opposite effect will end immediately [24]. In terms of indirect effects, the relationship between NPL, ROE, and Z-score is a partial mediation relationship. Combining these relationships, it can be said that bank stability is explained by both the two variables including credit risk and bank performance. Credit risk has a direct impact on bank stability, when credit risk increases, bank stability decreases. Bank performance increases, bank stability tends to decrease. When credit risk increases, combined with bank performance increased, banks' volatility will certainly increase. From this judgment, recommendations on reducing credit risk and improving bank stability are proposed. The groups of proposed solutions include the group of solutions for credit risk management, the solution group to reduce operating costs, the solution group to increase non-interest income, and the solution of capital structure management.

\subsection{Policy implications}

From the research results, the research proposed implications for the management of Vietnam commercial bank's focus on credit risk management.

Firstly, banks need to enhance credit risk governance to reduce the loan loss provision ratio. Commercial banks need to pay more attention to lending to reduce nonperforming loans, not lending to customers who do not have a healthy financial capacity.

Secondly, banks need to classify debts and make provisions for credit losses based on combining with internal credit ratings according to current regulations, strengthening inspection and supervision in the debt classification process and the bank should accept a decrease in profits due to the provision, as these will be the money used to handle loans when non-performance loans are incurred, avoiding the bank's crisis based on bad debt as well as excess liquidity.

Finally, banks need to build and perfect the risk management system to comply with Basel II standards. Identification of risk signs is one of the most important steps in the credit risk management process. Identification of the warning signals for a loan with a risk probability of exceeding the permitted standard is the most important and least expensive for the bank. Identifying and forecasting credit risks is one of the areas that need to be improved and carried out regularly and continuously. 


\subsection{Limitations}

The study was conducted for the case of Vietnam but there was no comparison with other countries.

Conflicts of Interest: The author declares that there are no conflicts of interest regarding the publication of this paper.

\section{References}

[1] M. Abreu, V. Mendes. Commercial bank interest margins and profitability: evidence for some EU countries. In Pan-European Conference Jointly Organised by the IEFS-UK \& University of Macedonia Economic \& Social Sciences, Thessaloniki, Greece, Vol. 34, No. 2, pp. 17-20. (2001).

[2] S. O. Adeusi, F. T. Kolapo, O. A. Aluko. Determinants of commercial banks' profitability: Panel evidence from Nigeria. Int. J. Econ. Commerce Manage. 2(12) (2014), 1-18.

[3] A. A. Alchian, H. Demsetz, The Property Right Paradigm, J. Eco. History. 33 (1973), 16-27.

[4] C. Alexiou, V. Sofoklis. Determinants of bank profitability: Evidence from the Greek banking sector. Econ. Ann. 54(182) (2009), 93-118.

[5] F. N. Alshubiri, Determinants of financial stability: an empirical study of commercial banks listed in Muscat Security Market. J. Bus. Retail Manage. Res. 11(4) (2017), 192-200.

[6] P. T. K. Anh, Handling bad debts and credit growth at Vietnamese commercial banks. Ministry of Finance website, Institute of Strategy and Policy. Retrieved Oct. 23 2019 from http:/ / tapchitaichinh.vn/ngan-hang/xu-ly-no-xau-va-tang-truong-tin-dung-tai-cac-ngan-hangthuong-mai-viet-nam-309460.html

[7] P. P. Athanasoglou, S. N. Brissimis, M. D. Delis. Bank-specific, industry-specific and macroeconomic determinants of bank profitability. J. Int. Financ. Mark. Inst. Money. 18(2) (2008), 121-136.

[8] M. Baron, Countercyclical Bank Equity Issuance, Rev. Financ. Stud. 33 (2020), 4186-4230.

[9] Basle Committee. Credit Risk Modelling: Current Practices and Applications Basle Committee on Banking Supervision, Bank of International Settlements, Basle, Switzerland. (1999).

[10] A. N. Berger, R. DeYoung. Problem Loans and Cost Efficiency in Commercial Banks. Working paper, Office of the Comptroller of the Currency, (1995).

[11] M. Bofondi, G. Gobbi. Bad Loans and Entry in Local Credit Markets. Bank of Italy, Mimeo, 2003.

[12] P. Bourke. Concentration and other determinants of bank profitability in Europe, North America and Australia. J. Bank. Finance, 13(1) (1989), 65-79.

[13] M. Carlson, D. C. Wheelock. Interbank Markets and Banking Crises: New Evidence on the Establishment and Impact of the Federal Reserve. Amer. Econ. Rev. 106(5) (2016), 533-537. 
[14] V. Castro. Macroeconomic determinants of the credit risk in the banking system: The case of the GIPSI. Econ. Model. 31 (2013), 672-683.

[15] J. Chant. Financial stability as a policy goal. Essays Financ. Stab. 1 (2003), 57-58.

[16] M. M. Cihák, H. Hesse. Islamic Banks and Financial Stability: An Empirical Analysis. IMF Working Paper No. 08/16. (2008).

[17] G. D. Nicolo, M. G. Zephirin, P. F. Bartholomew, J. Zaman. Bank consolidation, internationalization and conglomeration: Trends and implications for financial risk. IMF Working Paper No. 03/158. (2003).

[18] R. I. Diaconu, D. C. Oanea, The Main Determinants of Bank's Stability. Evidence from Romanian Banking Sector, Procedia Econ. Finance. 16 (2014), 329-335.

[19] A. Dietrich, G. Wanzenried, Determinants of bank profitability before and during the crisis: Evidence from Switzerland, J. Int. Financ. Mark. Inst. Money. 21 (2011), 307-327.

[20] Gamaginta, Rokhim R (2015). The stability comparison between Islamic banks and conventional banks: Evidence in Indonesia. In $\mathrm{H}$ A El-Karanshawy et al. (Eds.), Financial stability and risk management in Islamic financial institutions. Doha, Qatar: Bloomsbury Qatar Foundation. 2015.

[21] J. Goddard, P. Molyneux, J.O.S. Wilson, The profitability of european banks: a cross-sectional and dynamic panel analysis, Manchester School. 72 (2004), 363-381.

[22] J. A. Haslem. A statistical analysis of the relative profitability of commercial banks. J. Finance, 23(1) (1968), 167-176.

[23] J. Kakes, G. J. Schinasi. Toward a Framework for Safeguarding Financial Stability (June 2004). IMF Working Paper No. 04/101.

[24] D. Iacobucci, N. Saldanha, X. Deng, A Meditation on Mediation: Evidence That Structural Equations Models Perform Better Than Regressions, J. Consumer Psychol. 17 (2007), 139-153.

[25] P. Jackson, W. Perraudin. The Nature of Credit Risk: The Effect of Maturity, Type of Obligator, and Country of Domicile. Financial Stability Review, November, Bank of England: London. pp. 122-150. 1999.

[26] M. C. Jensen, W. H. Meckling. Agency Costs and the Theory of the Firm. J. Financ. Econ. 3(4) (1976), 305-360.

[27] S. H. Kargi. Credit risk and the performance of Nigerian banks. Thesis, Department of Accouting, Ahmadu Bello University, Zaira Nigeria. 2011.

[28] T. F. Kolapo, R. K. Ayeni, M. O. Oke. Credit risk and commercial banks' performance in Nigeria: a panel model approach. Aust. J. Bus. Manage. Res. 2(2) (2012), 31-38.

[29] C. Memmel, P. Raupach. How do banks adjust their capital ratios? J. Financ. Intermediation, 19(4) (2010), 509-528. 
[30] F. S. Mishkin. The economics of money, banking, and financial markets. 7th ed., USA: Columbia University, pp. 411-434. (2004).

[31] F. S. Mishkin. How big a problem is too big to fail? A review of Gary Stern and Ron Feldman's too big to fail: the hazards of bank bailouts. J. Econ. Literature, 44(4) (2006), 988-1004.

[32] A. H. M. Noman, S. Pervin, M. M. Chowdhury, H. Banna. The effect of credit risk on the banking profitability: A case on Bangladesh. Glob. J. Manage. Bus. Res. C Finance. 15(3) (2015), 41-48.

[33] A. Hoffmann, G. Gunkel, Bank filtration in the sandy littoral zone of Lake Tegel (Berlin): Structure and dynamics of the biological active filter zone and clogging processes, Limnologica. 41 (2011), 1019.

[34] F. Pasiouras, A. Liadaki, C. Zopounidis. Bank efficiency and share performance: Evidence from Greece. Appl. Financ. Econ. 18(14) (2008), 1121-1130.

[35] E. Richard, M. Chijoriga, E. Kaijage, C. Peterson, H. Bohman. Credit risk management system of a commercial bank in Tanzania. Int. J. Emerg. Mark. 3(3) (2008), 323-332.

[36] M.S. Saeed, N. Zahid. The impact of credit risk on profitability of the commercial banks. J. Bus. Financ. Affairs, 5(2) (2016), 2167-0234.

[37] M. Segoviano, C. Goodhart, Banking Stability Measures, IMF Working Paper 09/4. 2009.

[38] F. A. Takang, C. T. Ntui, Bank performance and credit risk management, Dissertation, Institutionen för teknik och samhälle, Skövde, 2008.

[39] Y. Tan. The impacts of risk and competition on bank profitability in China. J. Int. Financ. Mark. Inst. Money, 40 (2016), 85-110.

[40] T. W. Koch, S. S. MacDonald. Bank Management. South-Western Cengage Learning, 7th Edition, Chapter 13. 1995.

[41] M. Ulici, A. Chaibi, C. Rault, Shock And Volatility Transmissions Between Bank Stock Returns In Romania: Evidence From A VAR-GARCH Approach, J. Appl. Bus. Res. 30 (2014) 689-700.

[42] U. Uwuigbe, O. R. Uwuigbe, B. Oyewo. Credit Management and Bank Performance of Listed Banks in Nigeria, J. Econ. Sustain. Develop. 6(2) (2015), 27-32. 